\title{
Kanon: Eenheid en diversiteit
}

\author{
Pieter M Venter \\ Departement Ou-Testamentiese Wetenskap \\ Universiteit van Pretoria
}

\begin{abstract}
Canon: Unity and diversity

An analysis of the present post modern situation indicates resistance to the idea of "canon" understood in terms of a normative final collection of literature. The disciplines of textual criticism and canon history show that canons function in a larger social context and cannot be understood only in terms of its literary aspect. At present two parallel viewpoints on canon are found in the Christian church. The "objective" viewpoint stresses the final literary form of the Biblical canon. It cannot, however successfully indicate the unity of the canon without acknowledging the social context of the users of the canon. The "subjective" viewpoint clearly indicates the contingent aspect of the canon, but has problems with the way its authority operates. The probable way to go about the postmodern society is to acknowledge the paradigmatic character of the canon's contents and the dynamical process of canonization and decanonization in which a canon is involved.
\end{abstract}

\section{PROBLEMATIEK}

Die Bybel is ' $n$ antieke dokument waarin godsdienstige ervarings, refleksie op die werklikheid en nadenke oor die verhouding tussen God, die mens en die wêreld, verwoord is. Die konseptualisering in die Bybel van hierdie aangeleenthede lê aan die basis van voortgaande teorievorming oor godsdiens en werklikheid binne steeds nuwe kontekste. Hierdie dokument het nog altyd 'n uitsonderingsposisie in die kerk beklee as primêre basis van die Christelike kerk se interpreterende tradisie. Die aanspraak van die inhoud van die Bybel om normatief vir voortgaande teologisering te wees en die erkenning van hierdie aanspraak, word uitgedruk met die term "kanon".

Die begrip "kanon" word al vir etlike eeue in die Christelike kerk gebruik om die status van die Bybel aan te dui. Sedert Athanasius dit in die vierde eeu begin gebruik het om die gesag van die Bybel vir die kerk te omskryf, is dit 
toenemend met die finale vorm van die Bybel vereenselwig. ${ }^{1}$ In Protestantse kringe het die aspek van die finaliteit van die inhoud van die Bybel en die finale afbakening van die vorm daarvan, die oorwegende betekenisdraende elemente van die begrip "kanon" geword. Die inhoudsvulling van die kanonbegrip het ook grootliks gesteun op die sosiale dinamiek van mag en eksklusiewe gesag.

Hierdie bepaalde opvatting van die begrip kanon en die gebruik van die Christelike kanon in daardie sin, het egter voor ' $n$ krisis te staan gekom. Vir die huidige wêreldgemeenskap, wat as oorwegend "post-modernisties" getipeer kan word, het die idee van 'n kanon, veral as dit so verstaan word, onaanvaarbaar geword. Daar het weerstand begin kom teen die kanonnosie, veral wanneer dit in die sin van rigiede gesag verstaan word. Om hierdie teenstand te verstaan moet redelik uitvoerig stilgestaan word by verskillende tendense wat die hedendaagse wêreld kenmerk. Dit sal dan duideliker word hoekom toenemende verset ondervind word. ${ }^{2}$

Platvoet (1998:118-119) praat van die nuwe tyd as die "tweede aksiale tyd." In hierdie tyd het die tegnologie, demografie, institusionalisering, welvaart, skoling, kommunikasie en mobiliteit drasties verander. Volgens Platvoet (1998:118) het 'n proses van "de-elitisering" ontstaan. Sosiale stande het verdwyn en sosiale mobiliteit het toegeneem. Die welvaart van die laere klasse het vermeerder. Die deelnemende parlementêre demokrasie het die godsdienstige gesag vervang en die sentrale rol van gesag oorgeneem. Enige gesag wat aan ' $n$ instituut of 'n onbuigsame norm verbind word waaraan mens nie direk deel het nie, is onder verdenking. Die bemagtiging van die breë gemeenskap gaan saam met die vrylike en vinnige verspreiding van kennis. Alfabetisering is in byna alle samelewings aanwesig en "education permanente" (Platvoet 1998:119) het toegeneem. Vir Adriaanse (1998:328) het gemeenskappe onvermydelik verander in "knowledge-based systems." Voortdurende skoling word voorsien deur ' $n$ konstante stroom informasie wat die massamedia en die elektroniese kommunikasie in die vorm van die internet aanbied. Die inligtingsontploffing het die beheerders van kennis van hulle eksklusiewe magsposisie beroof. Enigiets wat grense probeer stel aan die ontdekking van nuwe inligting word as bedreiging beskou. 'n Poging om bepaalde inligting eksklusief te maak of ten koste van ander inligting tot die enigste te verhef, is gewoon nie meer aanvaarbaar nie.

\footnotetext{
${ }^{1}$ Die term "kanon" is eers sedert David Ruhnken se publikasie Historia critica oratorum Graecorum van 1768 gebruik as aanduiding van 'n afgeslote versameling geskrifte (vgl Smith 1998:295). ${ }^{2}$ Alhoewel die probleem van die kanon 'n wêreldwye verskynsels is, konsentreer ek in hierdie
artikel hoofsaaklik op die debat soos dit in Wes-Europa gevoer word.
} 
Volgens Platvoet (1998:118-119) stem die geloofsgemeenskap en die samelewing nie meer met mekaar ooreen nie. Die geloofsgemeenskap geniet nie langer meer enige voorrang of alleenaanspraak op die waarheid nie. Godsdienstigheid is boonop nie meer ' $n$ vanselfsprekendheid nie. Gelowiges moet nou opnuut 'n definitiewe keuse maak, nie meer teen ander godsdienste as sodanig nie, maar teen godsdiensloosheid. Hulle word toenemend gekonfronteer deur ' $n$ invloedryke groep mense wat geen behoefte het aan godsdiens nie.

Die invloed van ander godsdienste in die eie gemeenskap het ook drasties toegeneem. Die vinnige religieuse pluralisering van die huidige gemeenskap deur immigrasie in Europa het onder andere hiertoe meegehelp. 'n Nuwe demokratiese bestel en grondwet in Suid-Afrika het die Christendom van sy unieke gesagsposisie ontneem. Veraf en vroeëre vreemde godsdienste het deel van die samelewing geword en die moontlikheid gebied vir die eksploitasie daarvan. Die gelykwaardigheid van godsdienste word summier aanvaar en die uniekheid van die Christendom het in die slag gebly. Die geletterde religieuse elite van vroeër is nou vervang met die massa wat met kennis bemagtig is en self kan besluit oor sake, ook oor die godsdiens.

Boeve (1998:371) se ontleding van die huidige post-moderne gemeenskap is dat "all-encompassing master stories, including the religious traditions, have lost their plausibility. Post-modern society is characterised by plurality, the discovery of the other/otherness, and the consciousness of the particularity and contingency of each narrative." Gesien vanuit die hoek van dekonstruksie is rasionaliteit sowel as tradisie in die proses ondergrawe. Hettema (1998:392) sê dat dekonstruksie "... laid bare in textual interpretation ... the continuous process of differentiation that creates meaning; it has exposed the hidden plurality and countercurrents of seemingly univocal, reasonable appeals." Die verskynsel van dekonstruksie het uitgewys dat tekste noodwendig 'n pluriformiteit en verskeidenheid van interpretasies en aansprake meebring.

Die groot narratiewe wat die wêreld deur kennis en tegniek wou beheer, het hulle geloofwaardigheid verloor omdat hulle nie hulle beloftes kon nakom nie. Met die val van hierdie narratiewe het die proses van pluriformiteit tot ' $n$ hoogtepunt gekom. Dit het gelei tot die fragmentering van die mens se leefwêreld. "... one of the fundamental characteristics of postmodernity consists of the more general insight that the same reality can be legimately perceived in different and perhaps even incommensurable ways" (Boeve 1998:374). Daar is nie meer een groot narratief wat al die perspektiewe kan huisves of as arbiter van buite af kan beslis oor reg en verkeerd nie. Boeve (1998:374) beweer: 
In such a context of radical plurality the notions of 'canon' or 'tradition', in their classical authoritative and exclusivist significance seem to be completely outdated, as remnant of hegemonic narratives. Henceforth, no canon, no tradition can claim to be the sole way to truth, to be identical with the truth, especially in view of the most different and incommensurable religious traditions in our world. Nowadays tradition stand in plural, and implies, next to historicity and contextuality, the consciousness of its own radical particularity and contingency.

Jou eie tradisie word nou maar een tradisie naas baie ander. Die gevolg is dat die verband tussen geloof en religieuse identiteit aan die een kant en geloof en 'n bepaalde tradisie aan die ander kant, nou begin te verswak. Die normatiwiteit van die kanon begin verdamp. In sy soek na religieuse identiteit voel die persoon dan vry om fragmente te gebruik wat hom pas. "As a matter of fact, such a decanonization of the established religious tradition often goes hand in hand with the formation of new flexible canons, answering to no other criteria than the religious well-being of the subject" (Boeve 1998:375). Fragmente uit die religieuse tradisie word dan kommoditeite op die religieuse mark wat vir die verbruiker beskikbaar gestel word. Die "economizing narrative" (Boeve 1998:375) neem die tipiese religieuse funksie oor en muteer integrerende patrone.

Volgens Boeve (1998:3710) se analise is mark-georiënteerde relativisme en defensiewe fundamentalisme die twee teenoorstaande moontlikhede wat gebruik word om die nuwe situasie te probeer hanteer. Dit bring noodwendig mee dat godsdienstradisies gekonfronteer word en daartoe genoop word om die status van hulle eie godsdienstige narratief te ondersoek, die opvatting van tradisie wat dit huldig en die moontlikheid van dekanonisering.

Vos (1998:25) wys daarop dat 'n kanonieke grondslag juis weerstand oproep. Dit is onvermydelik dat daar 'n proses wat genoem kan word "dekanonisering" sal begin plaasvind. Alhoewel dit hoogs onwaarskynlik is dat in die huidige kennisgedrewe maatskappy kulturele prestasies en religieuse kennis net so oorboord gegooi sal word, is dit volgens Adriaanse (1998:328) so dat "[a]t least two of the phenomena constituting the canon syndrome, resistance to time and normativity, seem indeed destined to obsolescence." Platvoet (1998:93) kom tot die gevolgtrekking dat "... ook al zijn canonische godsdiensten vooralsnog manifest en zelfs dominant in de huidige fase van de godsdienstgeschiedenis aanwezig, zij zich in hun late najaarsbloei bevinden, omdat de privileges van de kleine elites die hen in de afgelopen drie millennia schiepen zijn gedemocratiseerd." Adriaanse (1998:329) se eie 
drastiese gevolgtrekking is dat "[c]anonicity in the original, solid sense of the word would be a once-only phenomenon in human history, a phenomenon inextricably bound up with premodern cultures."

In die lig van hierdie verandering van gemeenskappe dwarsoor die wêreld, ook alhier in Suid-Afrika, en die gevolge wat dit vir die bestaan en funksionering van die Christelike kanon inhou, het dit noodsaaklik geword om oor die konsep van kanon te herbesin, minstens oor die manier waarop dit tot hiertoe gebruik is. Die kanonnosie het, minstens in sy rigiede betekenis van outoritêre alleengesag, onaanvaarbaar vir die huidige tyd geword. Die huidige gemeenskap vra toenemend kritiese vrae oor kanon. Daar is basies twee vrae. Die een is oor die houdbaarheid van kanon as 'n normatiewe kriterium. Die ander is oor die wettigheid van prosesse van kanonisering en dekanonisering (vgl Boeve 1998:373).

Herbesinning oor wat ons met "kanon" bedoel, word gestimuleer deur navorsing na die ontstaan van die teks van die Bybelse kanon en die geskiedenis waardeur die verskillende Bybelse kanonversamelings gevorm is. Teen hierdie agtergrond wil ek in hierdie artikel besin oor die kanonnosie en 'n herkonseptualisering van die aard en funksie van die kanon oorweeg.

\section{DIE ROL VAN TEKSKRITIEK}

In sy tekskritiese navorsing het Ferdinand Deist op die bevinding gewys dat daar nooit so iets soos een enkele oorspronklike Hebreeuse teks bestaan het nie. Daar het 'n verskeidenheid van tekste bestaan. Dit het vir Deist (1992:45) die moontlikheid geskep dat ons “... may question and perhaps even change [the] interpretation of the sola scriptura principle, and consequently also [the] view of Scripture on fundamental level."

In sy navorsingswerk het Deist egter in 'n kontradiksie beland waaruit hy tydens sy leeftyd nie kon kom nie. Hy huldig die oortuigende standpunt dat 'n kanon nie slegs in terme van 'n teks alleen verstaan kan word nie. Kanonisiteit lê nie primêr op die vlak van literariteit, 'n geykte teks, die bepaalde woorde van 'n teks of inherent binne die teks self nie. ${ }^{3}$ Aan die ander kant kon hy nie werklik los kom van die idee van 'n gefinaliseerde dokument nie. Daar was vir hom eers sprake van kanonisiteit nadat die volledige literarisering van die kanon plaasgevind het. Daar was dus by hom 'n onverklaarde teenspraak tussen 'n kanontradisie wat met 'n meervoud van

\footnotetext{
${ }^{3}$ Platvoet (1998:98) wys daarop dat die ondersoek na kanons oorwegend "scriptocentrisch" is. Godsdiens word slegs uit die oogpunt van skrifproduksie verstaan. Platvoet (1998:100) maak die uiters belangrike stelling, dat "... de als vanzelfsprekend genomen aanname herzien moet worden dat canonvorming in de godsdienstgeschiedenis intrinsiek verbonden zou zijn met de ontwikkeling van schrift en dus uitsluitend voor zou komen in samenlevingen met schrift en in de godsdiensten van 'het boek'."
} 
tekste werk en een wat met 'n bepaalde literêre kanonteks werk (vgl Venter 1998a:583, 597-598). Dit is egter 'n probleem wat tans nog steeds ervaar word. In beginsel is die kanonisiteit van die Bybel nie in die eerste plek verbind aan sy skriftelikheid of sy afgebakende en finale vorm nie. Aan die ander kant staan die finale vorm waarin die Bybel as kanon gebruik word, nou al vir etlike eeue onveranderd vas en word in die praktyk kanonisiteit en finale vorm nog steeds met mekaar geïdentifiseer.

Die standpunt dat die kanonisiteit van die Bybel in prinsipe nie identies is met sy finale vorm nie, word grootliks gesteun deur tekskritiese navorsing. Dit is duidelik dat daar met 'n pluriformiteit van tekste rekening gehou moet word (vgl Venter 1998b:526-527). Daar was oorspronklik verskillende weergawes van die gesaghebbende geskifte met talle onderlinge variasies. Wat die Ou Testament betref was daar proto-masoretiese tekste wat vanaf 70 $\mathrm{nC}$ talle kere gekopieer is in Joodse geledere deur sogenaamde soferim en naqdanim (vokaal kundiges) wat dit van vokale voorsien het. Die oorlewerings is tussen die sewende en elfde eeu nC gekonsolideer en gefinaliseer toe verskillende groepe massorim bepaalde aantekeninge daar by gevoeg het. Hierdie aantekeninge het aan hierdie tekste die benaming "Masoretiese teks" besorg. Dit was veral die Ben Asjerverwerking daarvan wat algemene aanvaarding begin kry het en sedert die uitvinding van die boekdrukkuns as basis gebruik is vir die verskillende gedrukte uitgawes van die Hebreeuse Bybel. Teen daardie tyd het daar konsensus begin kom oor die omvang en bewoording van die Wet en die Vroeë Profete. Die gebruik het ontstaan om die Skrifprofete en die Geskrifte volgens die lys van Baba Bathra 14b in die Babiloniese Talmoed te rangskik. Hieruit is dit duidelik dat eenheid in die presiese bewoording van die Hebreeuse teks en rangskikking van sy "boeke" in 'n bepaalde volgorde iets was wat eers oor eeue stelselmatig uitgekristalliseer het. In die lig van hierdie navorsing het dit onhoudbaar geword om die kanonisiteit van die Bybel summier gelyk te stel met die vorm en die literariteit daarvan of slegs oor kanon te dink in terme van 'n gefinaliseerde en gefikseerde dokument.

Die ongenuanseerde vereenselwiging van kanon en kanonvorm word afgewys deur die navorsing van Armin Lange (2004:51-107). Hy het die fragmente van leerrolle en papiri wat sedert 1947 in die 11 grotte van Qumran by die Dooie See gevind is, bestudeer. Hierdie dokumente uit die tyd tussen die derde eeu $\mathrm{VC}$ en die eerste eeu $\mathrm{nC}$ bied inligting oor die proses van kanonisering gedurende daardie tyd. In die vergelyking van die 200 "Bybelse manuskripte" daar met die ander 700 manuskripte wat nie met die Bybel ooreenstem nie, kan 'n idee gevorm word oor hoe die proses van teksoorlewering en uiteindelike finalisering van die kanon verloop het. Deur te 
kyk na aanhalings en toespelings wat in die ander tekste voorkom, kom Lange tot die gevolgtrekking dat die Hellenistiese godsdienshervormings tussen die jare 175-164 vC 'n kritieke draaipunt in die oorlewering van godsdienstige tekste en die verstaan daarvan as Skrif teweeg gebring het.

Lange verdeel die 1145 aanhalings en toespelings wat die ander 700 tekste uit die Bybelse tekste maak in twee tydperke. Die ouer tekste kom uit die tydperk tussen Aleksander die Grote in $333 \mathrm{vC}$ tot by die regeertyd van die hoëpriester Jason in 175 vC. Die jonger groep kom uit die tyd tussen $175 \mathrm{vC}$ en die tyd toe Rome beheer oorgeneem het oor Judea onder Pompeius in 63 vC. In die ouer dokumente word uit Bybelse geskrifte aangehaal en toespelings gemaak sonder om voorkeur te gee aan enige bepaalde vorm van die Bybelse geskrifte. Die teksvorm is nie vasgepen net op een spesifiek bewoording nie. Die gedeeltes wat aangehaal word, gee God se woorde weer en verwys na God se geskiedenis met sy volk en word in daardie sin gebruik. Die tekste wat gebruik word, is gewoon 'n literêre medium wat die gebeure en bekendmaking van God uit die verlede weergee. Die vorm waarin dit gegee word het geen gesag op sy eie nie. Die gesag van die teks is dus glad nie gekoppel aan enige gestandaardiseerde vorm van die teks nie, slegs aan die inhoud wat dit oordra. Selfs geskrifte buite die Tora en die Profete word as gesagvol beskou en aangehaal. Daar is geen eenstemmige en gefinaliseerde versameling wat geoutoriseer is of wat met gesag vereenselwig word nie.

In die jonger tydperk tussen Jason en Pompeius is dit opvallend dat die dokumente uit Qumran meesal parabybels en eksegeties van aard is. Dit impliseer dat gesaghebbende tekste in hierdie fase baie meer prominent begin word het, dat daar 'n beweging van literatuur na skriftuur was en 'n groeiende beskouing dat sekere tekste 'n bepaalde gesag dra. Daar is egter geen aanduiding van 'n geslote versameling van gesaghebbende geskrifte nie. Selfs in hierdie tyd was die gebruik van die Bybelse oorlewering as kanon nie verbind aan 'n bepaalde gestandaardiseerde teksvorm of bepaalde teksversameling nie.

Wat hierdie geskrifte waarvan daar geen finale vorm of vaste versameling was nie, tot 'n eenheid saamgebind het, kan volgens Lange verstaan word uit 'n geskrif Miqsat Ma'aseh Ha-Tora (MMT) uit die tweede helfte van die tweede eeu vC. Daarin word die vraag gevra na die onderlinge verband van die Essene, die Jerusalemse hoëpriester en die party van die Fariseërs. Die eenheid wat tussen hulle ervaar is, ten spyte daarvan dat daar nie 'n gestandaardiseerde teks of afgebakende Skrifversameling was nie, was geleë in die onderlinge bereidheid om die Skrifte as gesagsbron te ervaar. Op die metavlak van die gemeenskaplike benadering van die werklikheid vanuit die Skrifte, het hierdie onderskeie groepe eenheid met mekaar ervaar. 
Wat belangrik is in Lange se navorsing is die aanduiding dat die gesagvolheid van geskrifte nie noodwendig aan gefikseerdheid of aan 'n vaste lys verbonde hoef te wees nie. Dit kan as kanon funksioneer selfs in 'n voorgefinaliseerde vorm

Ook uit ' $n$ ander hoek word aangetoon dat die kanonnosie nie noodwendig aan die afgebakende omvang of fisiese gestalte van die kanon verbind hoef te wees nie. Loader (2005:1035-1037) beredeneer dat die idee van een groot kanon versameling nie van die vroegste Christen-era kon bestaan het nie. Dit was fisies onmoontlik. Dit het eers sedert die instelling van die kodeks in die $4 \mathrm{e}$ eeu $\mathrm{nC}$ fisies moontlik geword om al die materiaal saam te bundel en as een "boek" te beskou. Tot op daardie stadium was die materiaal op boekrolle en kon dus nie fisies op een dokument kom nie. Dit was hoogstens 'n versameling van boekrolle wat per afspraak bymekaar gehou is. Met die kodeksvorm en sy inbind van bladsye het dit vir die eerste keer moontlik geword om al die materiaal in een fisiese boek saam te bind. Die idee van 'n versameling van verskillende rolle of "boeke" is ook behou. Dit is egter eers deur die tegniese vooruitgang van die kodeks dat dit moontlik geword het om al die dele fisies een boek te maak. Tradisioneel het ons wel vandag ' $n$ bepaalde kanon met 'n bepaalde omvang. Dit is 'n gegewenheid. Daar is egter geen interne netwerk wat die materiaal as eenheidsbeginsel of teologiese rasionaal saambind nie. Die kanonisiteit daarvan is ook nie primêr in die bepaalde samestelling te vind nie. Daar was 'n kanon selfs nog voor dit een gebundelde volume was.

Hierby sluit Smith (1998:307) aan in sy verklaring: "Canonization, as a secondary process, is inseperable from modes of production; it is as much an affair of technology as theology." Hy sien dus in die aanvaarding van die kodeksvorm in die vierde eeu in die westelike deel van die Christendom die hoof oorsaak daarvoor dat die idee van eenheid en afgeslotenheid in die Bybelse materiaal geskep is. Die tegniese proses om van bibliotheke 'n biblion te maak, het die teologiese idee laat ontstaan dat kanon te doen het met 'n vasgestelde boek tussen twee buiteblaaie (vgl Smith 1998:308). In die Roomse en Protestantse kanons was dit die boekdrukkuns wat hoofsaaklik tot die geslotenheid van hulle kanons bygedra het. Dit lei tot die impulsiewe aanname, dat "[f]rom an ethnographic point of view, what appears within the manuscript or printed text of a Bible is for many Christian readers not only canonical but original" (Smith 1998:308). Dit was egter grootliks die rede daarvoor dat die gedrukte en gefinaliseerde vorm van die kanonteks op die lange duur gelykgestel is met die kanonisiteit daarvan.

Uit die hoek van teksritiek word die begrip "kanon" in die sin van absolute afgebakende vaste versameling materiaal dus uitgedaag deur die 
ontdekking van nuwe geskrifte soos die by Nag Hammadi en die Dooie Seerolle. Kanons funksioneer wel ook as geskrewe dokumente, maar nie noodwendig eers in 'n gefinaliseerde vorm daarvan nie. Alhoewel die bepaalde vorm van die Christelike kanon nou reeds vir eeue onveranderd vas staan, is die kanonisiteit van die Bybel in beginsel nie in daardie geykte vorm as sulks geleë nie.

\section{DIE ROL VAN KANONGESKIEDENIS}

Van der Kooij (1998:161) stem met Lange se idee saam dat die tweede eeu $\mathrm{vC}$ ' $\mathrm{n}$ baie belangrike en kritiese stadium in die kanonproses was. Daar was in daardie tyd wel 'n bepaalde losse versameling van voorvaderlike boeke wat "als een welomschreven collectie" gedien het. Van der Kooij (1998:161) se oortuiging is egter dat hierdie kanonisering "... niet als een beslissing, maar veeleer als een proces moet worden verstaan." Vir Van der Kooij (1998:158) is dit uit die kanongeskiedenis duidelik “... dat een canonieke status van de boeken niet per definitie een gestabiliseerde of gestandaardiseerde teksoverlevering impliceerde."

Wanneer Van de Beek (1998:50) oor die gebeure by Jamnia in die laaste helfte van die eerste eeu nC nadink, is hy oortuig dat die vasstelling van die kanon eerder 'n erkenning as 'n besluit was, omdat dit eintlik die einde van 'n proses was: "Op de synode werd alleen maar vastgelegd, wat allangs als zodanig functioneerde." Daar was alreeds 'n proses aan die werk wat met die omgang van die inhoud te doen gehad het en die innerlike oortuiging laat ontstaan het dat dit gesaghebbend is. "Aan de formele vasstelling van de canon ging een proces vooraf waarin deze groeide naar de huidige vorm" (Van de Beek 1998:50). Wat by Jamnia gebeur is slegs die manifestering vanuit eie kultuur en konteks van die ervaring met die oorgelewerde geskrifte. Vanuit sy sistematiese refleksie oor kanon en sy geskiedenis is Van de Beek (1998:54) oortuig dat "elk extern criterium is onvoldoende om het goddelijke gezag te claimen van deze teksten." Kanonisiteit is nie 'n formele begrip nie. Die Bybel is nie 'n onafhanklike waarheidsbron nie soos dit in die neoCalvinisme gesien word nie. Die gesag daarvan is verbind aan 'n godsdienstige gemeenskap wat die oortuiging van sy kanonisiteit met mekaar deel.

Hollander (1998:177) wys daarop dat die interkerklike twiste gedurende die tweede en derde eeu $\mathrm{nC}$ daartoe gelei het dat dit noodsaaklik geword het om kanonlyste op te stel. Hierdie lyste het aanvanklik van mekaar verskil. Die kerk was verspreid deur die Romeinse Ryk en dieselfde kanonlyste is nie oral gebruik nie. Een van hierdie lyste was die Canon Muratori uit die einde van die tweede eeu nC wat deur die Milaanse bibliotekaris Muratori in 1740 gevind 
is en na hom vernoem is. Dit was deur die invloede van teoloë soos Athanasius en Augustinus dat daar op die lange duur eenvormigheid in hierdie lyste gekom het.

Wanneer Janse (1998:241) ondersoek instel na die historiese dryfkragte agter die kanonisering van die konfessies in die Duitse Protestantisme van die sestiende-sewentiende eeu nC, kom hy tot die slotsom "... dat politieke en theologische krachten dienstbaar werden gemaakt aan een arrangement dat diende ter waarborging van orde en veiligheid als conditio sine qua non voor een geordende en vreedzame samenleving."

Hierdie enkele strepe uit die kanongeskiedenis wys daarop dat kanonisering 'n sosiale proses is binne 'n historiese konteks waarin groepe hulle bepaalde oortuigings formaliseer deur die materiaal wat hulle skep en deur die bepaalde keuse wat hulle maak van beskikbare tradisionele materiaal wat hulle as kanons vasstel. Die bepaalde versameling geskrifte wat by 'n bepaalde groep aangetref word, manifesteer daardie groep se sienswyse. "Teksversamelings was die produkte van verskillende interpreterende geloofsgemeenskappe wat binne 'n bepaalde stel van omstandighede daardie tradisies op 'n bepaalde wyse verkonkretiseer het en as hulle gesaghebbende vertolking van die gemeenskaplike tradisie gebruik het." (Venter 1998b:512). Kanonisering het nie net met verskillende fases in die geskiedenis vanaf die middel van die tweede eeu voor Christus tot in die eerste eeu na Christus te doen nie, maar ook met drie interaktiewe konsentriese vlakke. Op die heel omvattendste vlak staan die sosio-historiese konteks waarbinne geloofsgemeenskap(pe) leef en werk. Binne hierdie buitesone kom alles wat met tradisie en verbalisering van geloof te doen het ter sprake. In die kern van hierdie twee buitesones van sosio-historiese omstandighede en literêre dryfkragte verloop die uiteindelike opbou, fiksering en voortgaande gebruik van die Bybelse kanon (vgl Venter 1987:767-8).

Kanonversamelings is verder ook die ideologiese rekord van geloofsgroepe. Die versameling geskrifte wat by Qumran gevind is, is ' $n$ aanduiding van die bepaalde ideologie wat daar aangehang is en tot uiting gekom het in die geskrifte wat hulle produseer en repliseer het. Wanneer die dokument van Ben Sira wel voorkom in die Septuaginta-versameling, wat later uitmond in die Vulgaat en van daar in die Rooms Katolieke kanon, maar glad nie in die Masoretiese teks en van daar in die Protestantse kanon nie, wys dit dat daar by die groep(e) wat vir die Septuaginta verantwoordelik was aanverwante, maar tog verskillende ideologieë aan die werk was waarvolgens die versamelings gesaghebbende geskrifte bepaal is. Wanneer die Etiopiese Henog ontbreek by sowel die Septuaginta-versameling asook die Hebreeuse versameling, dui dit weer op 'n ander tradisie wat in die Etiopiese kanon 
aanwesig was. Die insluiting van Daniël in die Masoretiese versameling met opsigtelike weglating van Een Henog en ook Ben Sira, dui op 'n bepaalde ideologie wat aan die Sadokities-Rabbyns-Farisese tradisie gekoppel kan word.

Op grond hiervan kan die drievlakkige proses wat hierbo aangetoon is, nog breër uitgewerk word (vgl Venter 2002:471-472, 485). In aansluiting by die drie konsentriese sirkels wat hierbo aangetoon is, maar nou in omgekeerde orde, kan aangetoon word dat die finale vorm van 'n bepaalde groep se kanon een is wat in dialoog met ander groepe se kanonvorming tot stand gekom het. Die bepaalde seleksie is gedoen binne die raamwerk van 'n groot klomp gemeenskaplike materiaal, maar tegelyk in debat met ander groepe wat ' $n$ ander finale keuse uitgeoefen het. Kanonisering behels dus nie net keuses nie, maar wys ook in dialoog met ander keuses bepaalde materiaal af. Tweedens is die bepaalde "boeke" wat in 'n versameling opgeneem is, sowel die wat gemeenskaplik met ander groepe is, asook die wat eksklusief aan een versameling is, die finale uitpresipitering van ' $n$ proses met verskillende lae. Vanaf ' $n$ moontlik mondelinge fase tot ' $n$ finale skriftelike fase is elke boek opgebou deur die bestaande oorlewering telkens te herkontekstualiseer en selfs te herkonseptualiseer. In die finale fase is daar nog steeds gefossileerde reste van die oudste vorms van die boek. In die lig van voortdurende nuwe ideologies-sosio-historiese kontekste is die inhoud herskryf om teologies gesaghebbend te wees vir elke nuwe tyd. Elke Bybelboek in ' $n$ bepaalde kanon verteenwoordig dus op sy eie ' $n$ eeuelange dialoog tussen ouer en nuwer en eietydse opinies. Dit wys op die derde vlak waarop kanonisering funksioneer. Die oneindig gevarieerde samestelling van die gemeenskap bring mee dat die vraagstukke waarmee ' $n$ tyd gekonfronteer word op verskillende wyses beantwoord word. Deur die wyse waarop die gesaghebbende tradisie betrek word in ' $n$ bepaalde keuse of rangskikking van materiaal, kan 'n bepaalde ideologiese visie onderbou word en in debat met ander opinies binne dieselfde tradisie gestel word.

So dui die nosie van kanon nie net op 'n literêre finaliteit nie, maar op 'n verweefde sosiaal-ideologiese proses. ' $n$ Kanon het histories nie net te doen met gefikseerdheid nie, maar ook met 'n veelfasettige proses.

\section{DIE PROBLEMATIEK VAN EENHEID EN VERSKEIDENHEID}

In aansluiting by die proses soos dit hierbo beskryf is, word daar in die hedendaagse besinning oor die fenomeen van kanons, besonder klem gelê op die rol van die geloofsgemeenskap. Die aanduiding van 'n boek as heilig of kanoniek is eerder ' $n$ retrospektiewe as prospektiewe saak. Die boek self 
maak nie noodwendig aanspraak op heiligheid nie. Dit is eers latere gebruikers wat dit aan die boek toedig. Die geskiedenis van kanon het nie soseer met die oordra daarvan te doen nie, maar eerder met die resepsie daarvan. Smith (1998:299) dink dat "[a]uthority and power inhere less in the book than in the capacity to manipulate the book, the language of the text, in such a way exegetically as to create parole, inviting both a sense of plausibility and conviction."

Smith (1998:299-302) onderskei tussen twee tiperings van kanon. In die een tipering lê die klem op die status van die kanon. In die ander geval lê die klem op die presiese grense en beperkings van die kanon. In die eerste opvatting is die gebruik van die kanon, in byvoorbeeld die rituele van die geloofsgemeenskap, meer dominant en die grense van minder belang. Die situasie dra dus die kanon. In die ander geval dra die kanon homself en het hy gesag op sy eie. Sy afgeslotenheid en gefikseerdheid ondersteun hier sy kanon gesag. Die Protestantse model van die Bybel leun veral sterk oor na hierdie tweede opvatting. Dit is dan ook opvallend dat die vraag na die eenheid van die kanon 'n tipiese Protestantse vraagstuk is.

Helmer \& Landmesser (2004:3) verwys na 'n kanonopvatting in subjektiewe en objektiewe terme. Die Bybelteks bly altyd oop vir voortgaande subjektiewe aktualisering van die inhoud daarvan. Dit is nie dooie letters nie maar die basis van 'n lewende tradisie wat daadwerklik bydra tot die belewing van kontemporêre realiteit. Die eenheid van die kanonteks word nie net bepaal op grond van sy fisiese voorkoms nie, maar ook deur die gebruikers van daardie teks. Aan die ander kant is daar egter ook iets "objektief" agter die teks wat 'n bepaalde tradisie aandui wat histories onderliggend is aan die bepaalde kanonversameling. Die willekeurige gebruik of selfs verandering aan die kanonteks word uitbalanseer deur presies die selfde kanonversameling wat gehandhaaf word en in die kerk gebruik word. ${ }^{4}$

Albei hierdie opvattings van oop/subjektief en afgeslotenheid/objektief, kom in die Christelike kerk voor. In die kerke waar die liturgiese en kerklike jaar die gebruik van die Bybel bepaal, is die siening van die kanon baie "oper". In die Protestantse kerk is die opvatting baie meer aan die gefikseerdheid van die kanon verbind en die hele Bybel word in al sy dele as van gelyksoortige waarde beskou sodat alles teen die agtergrond van die geheel gelees moet word en die kontekstuele raamwerk, hoewel belangrik, sekondêr in waarde is tot die geskrif. Hierdie laasgenoemde siening is 'n beskouing wat eintlik eers teen die vyftiende en sestiende eeu nC ontstaan het, veral in die Protestantisme. Dit was in die neo-Calvinisme dat hierdie siening op die spits gedryf is. Volgens Smith (1998:302) moet in die opvatting van die kanon

\footnotetext{
${ }^{4}$ Vergelyk die probleem waarmee Deist geworstel het by 2 hier bo.
} 
gewaak word om een van hierdie twee opvattings oor die ander opvatting te transponeer of dit te gebruik ten koste van die ander. Die kanonnosie kan nie net in terme van een van hierdie twee opvattings gedefinieer word nie.

\subsection{Die eenheid van die kanon as veral Protestantse vraagstuk en as uitloper van 'n "objektiewe” kanonbeskouing.}

Wat die huidige na-moderne tydperk kenmerk, is die bewustheid dat daar naas jou eie standpunt ook ander legitieme standpunte is (wat maklik kan verloop in relativisme), die bewustheid van heterogeniteit of pluriformiteit, die verlammende onmag om aan alle standpunte reg te laat geskied en die frustrasie om die verskeidenheid van perspektiewe te ontken. Die beskermingsmeganisme van fundamentaliste, tradisionaliste en dogmatiste teen hierdie tendense is om naarstig aan hulle eie tradisie as die absolute narratief van die waarheid vas te klou. Hulle voel bedreig deur die postmoderne konteks en is beangs vir die eksistensiële onsekerheid wat pluralisering meebring. Hulle val terug in 'n tipiese modernistiese houding. Die eie religieuse tradisie word gesien as die enigste bron van waarheid en waarde. Wat die kanon betref word 'n gefikseerde kanon die enigste waarborg vir waarheid en bevryding. Die eie posisie word versterk deur besonder klem te lê op die finaliteit en tekstuele geslotenheid van die kanon. Die kanon volgens die opvatting van jou tradisie, word as absoluut en finaal beskou. Enige poging tot herkontekstualisering van die kanon word as verdag of subversief ervaar. Die oper opvatting wat die situasie op die gebruik van die kanon wil laat inspeel, word totaal ontmoedig. Die publikasie van vroeë Christelike literatuur, soos "Die Evangelie van Judas", word dan ook summier as 'n bedreiging vir die (eie opvatting van die) Bybelse kanon ervaar.

Die gegewenheid van die Christelike kanon en sy handhawing oor 'n paar eeue, is egter nie sonder betekenis nie. Ek het reeds bo aangedui dat geskrifte en ook die versameling van geskrifte die ideologiese rekords van gemeenskappe is. In die Bybel is 'n meervoud ${ }^{5}$ van uiteenlopende tekste saamgebring wat gesamentlik kanonies funksioneer. In die geskiedenis van kanonvorming, in die finalisering van kanoniese versamelings en in die gebruik van die Bybel as kanon, was daar naas talle sosiologiese en ideologiese faktore op die onderskei vlakke wat hier bo aangetoon is, ook nog oorwegings aan die werk wat aan die eenwees van die uiteenlopende inhoude 'n bepaalde hermeneutiese waarde wou gee.

Die gesagsaanspraak van die Bybel oor die aard van die verhouding tussen God, mens en wêreld, is gegiet in 'n bykans onoorsigtelike variasie van

\footnotetext{
${ }^{5}$ Die toenemende klem op die diversiteit van die Bybelse inhoud het die spanning met die saak van die eenheid van die Bybel onder groot druk geplaas.
} 
godsdienstige ervarings en teologiese konsepte. Die feit dat hierdie inhoude ten koste van ander inhoude op die ou einde bymekaar uitgekom het, bring noodwendig die vraag na vore na wat hierdie verskeidenheid saambind en van ander aansprake onderskei. Wat gee daaraan 'n eenheid? Is hierdie kohesie van Bybelse inhoude 'n inherente gegewene of is dit iets wat toevallig van buite af aan die materiaal toegedig word? Is dit 'n formele objektiewe eenheid wat met die vorm en die gefikseerdheid van die kanonversameling te doen het, of is dit ook 'n subjektiewe ad hoc eenheid wat eers deur die gebruiker(s) van die Bybel geskep word? As daar geen interne aanduiding in die kanonversameling self is hoekom die inhoud bymekaargevoeg is nie, moet die aanduiding van die eenheid dan buite die versameling self in die tradisie of die verantwoordelike geloofsgemeenskap(pe) gevind word? As die gegewene van die kanonversameling en die gefikseerde vorm daarvan nou reeds vir 'n paar eeue onveranderd vas staan, kan die Bybelgebruiker hierdie vorm van die kanon ignoreer wanneer hy/sy oor die versamelde inhoud van die Bybelse kanon nadink?

Die lees van die Bybel as kanon behels meer as die hantering van geïsoleerde en gefikseerde inhoude wat teologievorming bepaal. Dit gaan oor meer as net 'n hermeneutiese studie van hoe antieke tekste gelees word en in verskillende kontekste verstaan en toegepas word. Die parameters waarbinne hierdie konseptualisering plaasvind, is wel in die eerste plek die fisiese omvang van die kanonversameling. In die Protestantse Belydenisskrifte is daar baie van hierdie omvang en gedemarkeerdheid van die kanon gemaak. Die fout wat egter in die ortodoksisme gemaak is, was om daarby vas te steek en om die gesag van die Skrif summier en alleen gelyk te stel met hierdie fisiese vorm van die kanon. Die beskrywing van die Bybelse geskrifte as "kanon" het die outoriserende kanonisiteit van die geskrifte identies gaan maak met sy literariteit en 'n gefinaliseerde lys van boeke. Anders gesê: die vorm van die kanonversameling is identies gemaak met die funksie van die geskrifte. Die outoriteit van die Bybel is bykans uitsluitlik daaraan verknoop.

Die begrip kanon dra die intrinsieke eienskap dat 'n bepaalde eenheid daarvan verwag word om in die normale opvatting van die begrip gesagvol te wees. As daar aan die interne non-kontradiksie en konsistensie van die kanon getwyfel word, of wanneer daar aan die onderdele verskillende gewig toegeken word, kom die gesag van die kanon op die spel.

Die eenheid van die kanon versameling het egter nie net met die boekvorm daarvan te doen of die formele saamsit van die inhoud tussen twee buiteblaaie nie. Dit het selfs ook nie net met die inhoud van hierdie geskrifte te doen asof hulle inhoudelik met mekaar versoenbaar is nie. Die diversiteit van inhoud word nie besweer met een of ander inhoudsteologie nie. Wat hierdie 
materiaal saambind en die versameling gesagvol maak, strek veel verder as net die literariteit daarvan. Vir Helmer \& Landmesser (2004:5) is "[t]he unity of a world-view presupposed by different texts and the unity of the religious tradition they fund ... issues encompassing a unity extending beyond textual boundaries."

Hierdie eenheid kan egter nie maklik onder woorde gestel word nie. Dit is duidelik dat hierdie eenheid nie net op die literêre vlak gesoek kan word nie. Behalwe die oorlewering van bykans tweeduisend jaar wat die materiaal saambind om een volume te vorm, is daar geen interne getuienis in die literatuur self vir die kohesie van die materiaal nie. Die samebinding het ook met die hanteerders van die materiaal te doen en hulle bepaalde siening dat die materiaal bymekaar hoort. ${ }^{6}$ Die eenheid moet dus ook buite die Bybel gesoek word, of ten minste in wisselwerking met die groepe wat hierdie materiaal as ' $n$ eenheid sien. Wat die saak verder problematiseer, is dat daar meer as een groep by hierdie oorlewering van die Bybelse kanon betrokke is. Daar is 'n geweldige groot vlak van gemeenskaplikheid oor hierdie versameling, maar ewe eens duidelike verskille wanneer na die inhoud en omvang van die Protestantse Bybel, die Rooms Katolieke Bybel, die GrieksOrtodokse Bybel en die Etiopiese Bybel gekyk word.

Die begrip "eenheid" het boonop in die huidige tyd 'n opmerklike verskuiwing in inhoud ondergaan. Dit het verskuif vanaf ' $n$ formele en taamlik verabsoluteerde saak na een wat gekenmerk word aan diversiteit en pluriformiteit. Wat van verskillende sake 'n eenheid maak, is glad nie meer een atomistiese en outoritêre saak wat alles saambind en waaraan alles moet voldoen nie. Dit het eerder ' $n$ saak van interrelasie geword tussen verskillende ongelyksoortige, maar gelykwaardige entiteite. ${ }^{7}$ Nie een van die konstituente is dominant nie en ook nie een is absoluut nie. In baie van die huidige soeke na die eenheid van die kanon is daar nog steeds sterk reste van die modernisme wat eenheid in terme van sentrales en absolutes wil sien. In die huidige tyd het daar egter iets begin terugkom van die pre-moderne beskouings oor eenheid. Navorsing hier bo na die kanonvorming uit die premoderne tyd het in die proses weer relevant geword vir ons eie tyd.

In sy soektog na 'n eenheid in die kanon oorweeg Van Leeuwen (1998:399-402) Ricoeur se sinkroniese lees van die kanon. Hy kom tot die gevolgtrekking dat daar nie sprake is daarvan om die kanon as een teks te lees nie, hoofsaaklik vanweë die historiese uiteengeplaastheid van die inhoud.

\footnotetext{
${ }^{6}$ Die gebruikers bepaal die waarde van die geskrif. Hulle aktiveer kanoniese gesag daarvoor. Dit kan met die begrip regula fidei aangedui word.

${ }^{7}$ Vergelyk in hierdie verband die studiestuk van die Gereformeerde kerke in Nederland, "God met ons" (1981).
} 
Van Leeuwen (1998:402) bevind dat "[f]rom the outset one has to affirm that the Bible is a plurality of texts, the mutual relations of which cannot be grasped without a diachronical approach." Na aanleiding van Ricoeur se beskouing dat die kanon polifonies is, dat dit uit verskillende genres bestaan wat saam in hulle interaksie die Bybel uitmaak, dat dit 'n geslote depot van betekenis is wat oop staan vir 'n nimmereindigende geskiedenis van interpretasie, 'n afgeslote ruimte wat 'n onbeperkte ruimte van uitleg oopmaak, praat Van Leeuwen (1998:407) van die eenheid waarna die Christelike kerke soek as "this pluralistic unity of their common source, the Bible."

Loader (2005:1038-1046) wys daarop dat dit noodwendig is om na die eenheid van verskillende boeke te soek wanneer hulle in een fisiese boek bymekaar gesit word. Dit is egter moeilik om oor die eenheid te beslis wanneer die Protestantse kanon en die Roomse versameling van mekaar verskil. Daar is wel so iets soos 'n Bybelse kanon, maar dit het ongelukkig meer as een vorm. Loader (2005:1040) lei daarom af dat “... both Protestant and the Roman Catholic perspectives ... are wrought with deep tensions and deeply contradictory positions." Hy dui voorts ook verskillende inhoudelike en formele probleme aan wanneer daar na 'n harmoniese kanoniese eenheid gesoek word. Terwyl die praktyk om Bybelgedeeltes met ander Bybelgedeeltes te vergelyk, bedoel is om onsekerhede uit die weg te ruim en eenheid aan te dui, versterk dit inderdaad die ambivalensie tussen verskillende gedeeltes. Die tipiese Joodse gebruik om gedeeltes van die Bybel binne 'n buite-Bybelse konteks uit te lê, kom ook in die Nuwe Testament voor. In hierdie proses word die literêre konteks, die komposisionele sowel as die kanoniese aspek egter buite rekening gelaat. Dit blokkeer ook die poging om die geheel werklik binne 'n kanoniese konteks te verstaan. In ander gevalle, soos Matteus 1:23 en Jesaja 7:14, is daar volgens Loader eenvoudig verkeerd geïnterpreteer. Daar kom ook gevalle voor waar die Nuwe Testament gewoon die Ou Testament weerspreek, soos in die uitsprake oor ontug. Dit is dus duidelik dat die kanon as teologiese denkpatroon gelaai sit met probleme. Die vergelyking van die inhoud in 'n soektog na die eenheid binne die raamwerk van 'n kanon, stuit teen te veel probleme om sondermeer oplossings te vind.

Daar is natuurlik ook verskillende ander moontlikhede om te soek na die eenheid in die geweldige pluriforme aanbiedings wat die teks kenmerk. Die vraag kan gevra word watter dele die meeste gesag het. Dit lei tot of verskillende kanons of tot 'n kanon in die kanon. In hierdie kanon-in-die-kanon benadering word die eenheid van die kanon gesoek in terme van een komponent daarvan wat as die hoof saak of sentrifugerende nosie gesien 
word. Anders as in die Roomse kerk waar die gesag en eenheid van die Bybel ekklesiologies bepaal word, word dit in die Protestantisme teologies gedoen. By beide Luther en Calvyn was wat Alexander Schweizer (1808-1888) as "kanon in die kanon" bestempel, aan die werk. Daar is 'n teologies regulerende beginsel wat uit die kanon abstraheer word en waarvolgens die eenheid gesien word. Adriaanse (1998:320) noem dit egter 'n "emaciating quest", wat neerkom op die dekanonisering van die kanon. Volgens Smith (1998:309) is daar in kanonisering beide "hypercentrist and hypocentrist impulses." Volgens hom kom die gedagte van 'n kanon in die kanon neer op 'n "hypercentrist" benadering.

Volgens Ritschl (1998:385) is die vraag na die buiterande van die kanon nie meer in die sentrum van belangstelling nie, eerder die vraag na 'n moontlike Mitte van die Bybel, waarin die eenheid van Ou en Nuwe Testament gevind kan word. Volgens Ritschl (1998:386): "Nie lesen wir 'die Bibel' in ihren kanonischen Ganzheit, sondern immer nur 'in' der Bibel, indem wir Selektionen vornehmen, die ihrerseits meist von früher enstandenen Axiomen und Lehren geleiten wird ... ." Voor die finalisering van die kanon by Nicea in $\mathbf{3 2 5}$ het credo en leerformulering plaasgevind deur seleksie van Bybeltekte en samevattende interpretasies van langer Bybelgedeeltes of "stories." Struktureel word dieselfde proses steeds gevolg. Ontleen aan die Engelse wêreld dui "stories" nie op narratiewe teologie nie, "vielmehr sollte die inhärente Logik nicht nur der Erzählungen der Bibel, sondern auch die Logik der Aufeinanderfolge von Eindrücken, Gedanken und Argumenten in verschiedenartigen Bibelstellen exploriert werden" (Ritschl 1998:386). In die materiaal is daar 'n "Argumentationskette" (Ritschl 1998:387). Deur die samevatting van sulke argumentasiekettings ontstaan dan "Koagulationen" (Ritschl 1998:387) wat as leerstukke in die kerk funksioneer. Voortvloeiend hieruit is Ritschl (1998:389) oortuig "[d]er eigentliche Wahrheitsanspruch betraf in der Alten Kirche also nicht das Gesamt der biblischen Schriften, sondern die Lehren und Dogmen, von denen als gewiss angenommen wurde, sie gäben die zentralen Inhalte der Bibel wieder."

Naas hierdie benadering is daar ook nog die moontlikheid om na die eenheid te soek op die vlak van die tradisies wat onderliggend en inherent aan die Bybel self is. Dit kan beweeg in die rigting van Ritschl se "Koagulationen" hier bo. Die samehang word dan geprojekteer vanuit 'n studie van intra-Bybelse teologiese trajekte en hulle onderlinge samehang.

'n Derde moontlikheid is om vanuit die parameters van die kanongeskrif voortdurende nuwe teologiese teorieë in nuwe kontekste te muteer. Hier begin die konteks van die kanongebruikers die sleutelrol speel. Dit bring ons by die volgende afdeling. 


\subsection{Die subjektiewe kanonbeskouing}

'n Ander beskouing oor die kanon is die "oop" of "subjektiewe" benadering. Hier speel die situasie of die konteks waarin die kanon funksioneer die grootste rol.

Die Christendom het die idee van ' $n$ kanon van die Grieke oorgeneem. Die begrip is primêr afkomstig uit 'n literêre konteks. Dit is egter in die godsdiens toegepas as maatstaf vir aanvaarbaarheid in die groep. Dit was 'n aanduiding van groepsidentiteit. Die wat aan die maatstawwe van die kanon voldoen het, is in die godsdiensgemeenskap opgeneem en die wat daaraan voldoen het nie is buite die gemeenskap gehou. Die kanon volgens hierdie sienswyse het wyduiteenlopende interpretasieverskille toegelaat, maar was steeds die finale gesaghebbende bron waarop jy jou kan beroep. Vir Jenner \& Wiegers (1998:13) is kanons dus "[b]elangrijke, regulerende factoren in een ingewikkeld sociaal-cultureel en (godsdienst) politieke proces." Kanons kom normaalweg binne ' $n$ bepaalde godsdienstige of kulturele tradisie voor, maar het ook ' $n$ maatskaplike relevansie wat op interreligieuse en interkulterele vlak sy uitwerking het. Kanons is ook histories en kultureel bepaald, omdat dit 'n sosiaal-kulturele en lewensbeskoulike konsensus reflekteer wat die waardes en norms van ' $n$ bepaalde groep van 'n spesifiek periode in die geskiedenis weergee. Dit is die kodifikasie van 'n goedoorweegde seleksie uit 'n groter aanbod.

Wat natuurlik ook waar is, is dat kanons ' $n$ groot rol in die verkryging en handhawing van mag speel. Vir Ter Borg (1998:69) is 'n geslote kanon niks ander as 'n magsgreep nie. Politieke heersers en priesters gryp dit aan vir die vestiging en uitbreiding van hulle mag. Vos (1998:29) wys daarop dat die een wat die taak aanpak van kanonvorming outoritatiewe en selfs outoritêre bedoelings op die oog het. Hy/hulle wil verkondig, selfs in eksklusiewe sin, wat die geloofswaarheid is. Kanons is daarom die uitdrukking van ' $n$ bepaalde beskouing van wat die waarheid behels. Dit wil 'n bepaalde beskouing oor die heiligheid van gebruike en tradisies as algemene norm propageer. Die wat die ware geloof wil aanhang moet die inhoud van hierdie kanon as die enigste werklike en ware aanduiding van die waarheid aanvaar.

'n Kanon het verder te doen met 'n uiters dinamiese proses. Alhoewel kanons amptelik afgesluit en gefikseer is, is daar in die historiese en kontekstuele proses ' $n$ spel aan die gang tussen stabiliteit en verandering, kontinuïteit en diskontinuïteit. Alhoewel kanons stabiele produkte van die geskiedenis is, word hulle oor en oor herhaal, op verskillende plekke, op verskillende tye en in verskillende kontekste. In hierdie herhaling vind daar noodwendig re-kontekstualisasie en hermeneutiese herinterpretasie plaas. Boeve (1998:373) verklaar daarom dat "[c]anon/tradition and context are 
dynamically related. Changes in context challenge the reading of tradition, while this reading sheds new light on the changed context." Vir Ritschl weer is die Bybel 'n reservoir wat altyd slegs ten dele benut kan word. Volgens Ritschl (1998:381) behou die Bybelse kanon sy geldigheid omdat leerstukke daaruit afgelei kan word vir 'n bepaalde tyd en omstandigheid. Leerstukke kan verouder en dus gedekanoniseeer word, maar die Bybel in sy geheel nie. Die Bybel lei steeds tot nuwe kanonisering op dieselfde manier as wat modes, styl, ens, gekanoniseer word.

Omdat 'n kanon, soos Jenner \& Wiegers (1998:13) dit hierbo genoem het deel is van "... een ingewikkeld sociaal-cultureel en (godsdienst) politieke proces", is kanon gesien as rigiede gesag nie voldoende om te beskryf wat daar werklik tussen 'n kanoniese teks en 'n leser gebeur nie. Omdat 'n kanon 'n "sociocultural phenomenon" (Adriaanse 1998:327) is, is Smith (1998:303) se voorstel sinvol dat "... an ethnographic rather than a doctrinal approach to the issue of canon may prove fruitful and cause some revision of our commonly held presuppositions." Adriaanse (1998:327) wil selfs afsien van die teologiese konseptualisering van die kanon en "opt for a broader concept of canon and canonization ..." Hy erken die normatiewe aard van die kanon maar hang nie die norm aan nie. "The general concept of canon, canonicity, and canonization implies that there is no such thing as the canon. There are canons, each of them with normative claims which, as a matter of fact, are mostly conflicting with the claims of other canons" (Adriaanse 1998:327).

'n Bepaalde benaderingswyse kom by Hettema (1998:396) voor wat hy noem "a hermeneutics of canonical texts." Op grond van Rudolf Otto se Das Heilige van 1907 wat die verhouding met God beskryf as beide tremendum en fascinans, beklemtoon Hettema die fascinans wat die kanon vir die leser het. 'n Kanon is tydgebonde en vertoon 'n bepaalde onbuigsaamheid. Aan die ander kant ervaar die religieuse gemeenskap die aantrekkingskrag van die kanon in sy liturgie en sy tradisie. Die aantrekkingskrag van 'n kanon kom vanuit die verlede van die tradisie en bepaal die hede en toekoms van die tradisie. Omdat die godsdiensgemeenskap 'n verlede en 'n posisie in die hede het en 'n toekomsrigting, "the fascination of a canon can be expressed in terms of what I would call the qualitative dimensions of temporality. The fascination of a canon is a time-experience of concentration, elevation, or perhaps even disorientation in time" (Hettema 1998:397).

In die lig daarvan dat religieuse kanons en kanonieke tradisies tans ervaar word as iets wat "een repressieve, restrictieve en distintieve functie" (Jenners \& Wiegers 1998:304) het wat elite van nie-elite onderskei, bepaal wie binne 'n groep hoort en daarbuite, 'n verstrengeling is van wêreldlike en geestelike mag en die belange dien van bepaalde groepe, ontstaan daar 
verskillende vrae oor kanons. Daar is vrae soos of 'n kanon noodwendig 'n magsmiddel is, of dit ' $n$ onmisbare regulerende meganisme is vir die samelewing en of dit 'n onbewustelike verdedigingsmeganisme is teen anomie. Ander vrae is of die gebruik van kanons 'n stille dood moet sterf, soos sommige voorspel, of moet daar besin word oor die gebruik van kanons om die skerp kante daarvan uit te skakel?

Vos (1998:35) sny die probleem nog fyner aan. In die lig daarvan dat die konsep van kanon in die laaste eeue in diskrediet geraak het, wil hy beweer "dat het daarbij in de eerste plaats niet gaat om de inhoud van de geschriften die tot de canon behoren, maar om de status van de canon, als de exclusieve vorm waarin de werkelijkheid en waarheid van geloof en moraal worden gepresenteerd." Jenners \& Wiegers (1998:20-21) sluit by die gedagte aan dat status die bepalende faktor is. Hulle wys daarom op verskillende eksterne faktore wat aan die werk is by kanons. Hulle vra vrae soos, watter argumentasie en strategie bepaal die beslissing van wat kanon is al dan nie, in hoeverre is 'n kanon 'n godsdienspolitieke instrument, wat onderskei 'n religieuse kanon van 'n profane een, wat is die maatskaplike effek van religieuse kanons, hoe dra hulle tot religieuse identiteitsvorming by?

Nog ander eksterne faktore wat 'n rol speel in die bepaling van die status van 'n kanon, is wanneer heterogene godsdienstige geskrifte vir verskillende godsdienste in een en dieselfde samelewing gebruik word. Dit kan ook gebeur dat profane narratiewe die funksie van die godsdienstige kanon in die gemeenskap oorneem. Dit kan lei tot dekanonisering waarin die kanon van sy posisie gestroop word. Onder "dekanonisering" verstaan Adriaanse (1998:314) "gradual processes of invalidation of an extant canon." 'n Gekanoniserde teks roep noodwendig 'n dialektiese dekanonisering op. Om in momentum te bly, noodsaak die kanonieke teks opvulling van lakunes en deur interpretasie daarvan nuwe kontekstualiserings en toepassings.

Die belangrikste om by dekanonisering raak te sien is wat Vos alreeds hierbo aangedui het: die probleem lê nie by die inhoud nie, maar by die status wat 'n gemeenskap aan die Bybel toeken en hoe hulle dit formuleer. Dit is met ander woorde eerder die bepaalde verstaan van die kanonbegrip wat tot weerstand lei en wat dan gedekanoniseer moet word en nie soseer die gedagte dat die Bybel die kanon is nie.

\subsection{Die huidige uitdaging}

In die lig van die huidige pluriformiteitskultuur en sy kritiese ingesteldheid teenoor die Christelike narratief moet die uitdaging dus aanvaar word om die prosesse van kanonisering en dekanonisering in die huidige tyd te ontleed. Volgens Boeve (1998:378) behels dit naas die vrae wat hierbo aangedui is 
oor die funksionering van 'n kanon, ook nog twee ander tipe vrae. Eerstens moet duidelikheid gesoek word oor wat die Christelike kanon in die lig van hierdie huidige pluriformiteit is. Dit behels navorsing na onder andere pluriformiteit in die vroeë Christendom of selfs analogieë in struktuur en inhoud tussen verskillende godsdienste. Tweedens moet 'n antwoord gesoek word op relativisme se mening dat partikularisme geen aanspraak kan maak op waarheid en waarde in 'n pluriforme omgewing nie en die uitdaging van fundamentalisme wat die konteks van pluriformiteit ontken en enige poging tot rekontekstualisering ontmoedig. Daar moet 'n pad gesoek word uit hierdie skaakmat van fundamentalisme en relativisme uit waarin die normatiewe dimensie van kanon erken kan word sonder om die partikulêre en kontingente karakter van tradisie te verwerp en sonder om die voortgaande proses van (de)kanonisering uit te skakel.

Jenners \& Wiegers (vgl 1998:306) staan daarom vir die huidige tyd 'n neutrale model voor wat aan die sisteemteorie ontleen is. Volgens hulle kan hierdie tipe benadering reg laat geskied aan die prosesmatige karakter van die verskynsel van kanonieke tradisie. Dit kan duidelik uitspel wat bedoel word met die nosie van "kanon", empiries ondersoek hoe ouer kanonieke tradisies verdwyn en nuwes op die toneel kom en heuristies verklaar wat die oorsaaklike faktore is van hierdie voortdurende transformasie in die gebruik van 'n kanon. Hierdie model word egter gekortwiek wanneer die kanonieke tradisie sondermeer met die idee van 'n "norm" gelyk gestel word. Die normatiewe gesag wat 'n gemeenskap aan die kanoniek tradisie toeken kan dan op geen enkele wyse empiries nagegaan word nie en kanonieke tradisie word dan slegs gesien in terme van "oop" of "toe" (vgl Jenners\&Wiegers 1998:307).

Die Christelike godsdiens is sowel partikulêr/kontingent en terselfdertyd ook gesaghebbend. Die bepaalde partikulariteit van 'n perspektief sluit nie summier alle normatiwiteit uit nie. Hoewel 'n perspektief nie die bron van normatiwiteit is nie, kan daar op grond van sy historiese en kontekstuele gesitueerdheid in verhouding met al die ander perspektiewe iets gesien word van sy normatiwiteit.

Daar is twee aspekte hieraan verbonde. Daar is 'n relatiewe normatiwiteit ter sprake deurdat 'n perspektief/diskoers/narratief getuienis dra van sy onuitdrukbare andersheid en sy eie aansprake op absoluutheid temper. Tweedens is 'n perspektief sensitief vir sy "unrepresentable otherness" (Boeve 1998:378). Waar dit deur sy kontekstualiteit uitdrukking gee aan hierdie nie-finale uitdrukking, is dit vir die wat dit deel nie arbitrêr of vervangbaar nie, maar bindend. Narratiewe wat hierdie pad loop is nie hegemonies nie, maar kan genoem word "open ended narratives" (Boeve 
1998:378). Hulle maak nie aanspraak daarop om die eksklusiewe aanbod van die waarheid te wees nie, maar posisioneer hulleself in verhouding tot die absolute: daardie 'andere' wat nooit vasgevat kan word nie, maar waarvan jy moet getuig en wat elke getuie uitdaag as partikulêr en nooit identies met ander getuienisse nie. Volgens Boeve (1998:378) kan in hierdie "... postmodern condition of incommensurable plurality, particular traditions ... be valued normatively, precisely because of their sense for radical heterogenity, the absolute otherness finding expression in them."

In die pluriforme situasie kan die Christelike tradisie dus vashou aan sy normatiwiteit deur te verwys na sy inherente struktuur van oop narratief. Tradisievorming, kanonisering en dekanonisering, wat as proses noodwendig partikulêr is, verwys na God se voortgaande self-kommunikering wat die tradisie ten grondslag lê, maar keer op keer die tradisie uitdaag om die beperking van taal, konteks en tyd te erken. "Die funksie van die kanon lê baie meer op die aksie van God wat ìn hierdie kanon en sy tradisie mense só ontmoet dat elke outonome menslike mag en aanspraak op gesag gedekanoniseer word sodat dit God se almag as die enigste gesag bely" (Venter 1998:527). Die grote God wat homself bekend maak is die Absolute wat daartoe uitnooi om Hom 'n naam te gee en na weë te soek om sy wil onder woorde te bring. Sy absoluutheid ontmoedig egter enige poging om die tradisie met die absolute te identifiseer in 'n poging om die tradisie se normatiwiteit te verskans. Geen enkele tradisie kan dus aanspraak maak op finaliteit nie. Godsdienstaal word altyd gerelativeer in die lig van die onverteenwoordigbaarheid van die absolute. Daar kan slegs kontekstueel na hom verwys word en

... believing communities and individuals are forced time and again to use models, images, and vocabulary present in the contemporary context, while repeating, revising, or resignifying older models, images, and vocabulary referring to God. In this regard tradition consists of the continuing attempts to bear witness to God's self-communication, which is implied in ongoing process of canonization and decanonization.

(Boeve 1998:379)

\section{SAMEVATTING}

- Die huidige ná-moderne gemeenskap verset hom teen die idee van rigiede gesag wat hom van alle seggenskap ontneem. Daar is nie meer ruimte vir ' $n$ kanonbeskouing wat outoritêre mag aan die Bybel wil 
koppel en dit wil onderbou met die gefinaliseerde vorm van die Bybelse kanon nie.

- Tekskritiese navorsing wys dat 'n finale en gefikseerde vorm van die kanon iets is wat eers stelselmatig ontstaan het. Tekstualiteit en literêre finaliteit is nie noodwendig die essensiële kenmerke van 'n kanon nie.

- Die geskiedenis van kanonvorming wys op 'n verweefde sosiohistoriese proses. ' $n$ Kanon is die dokumentasie van die ideologie(ë) wat in bepaalde geloofsgemeenskappe van bepaalde tye gevolg word. Kanon kan nie los van die verweefde dinamiese prosesse in die samelewing verstaan word nie.

- Twee gedagterigtings staan langs mekaar in die Christelike kerk: 'n oop/subjektiewe benadering lê klem op die situasie waarin kanons gebruik word terwyl 'n afgeslote/ objektiewe benadering aan die hand van die afgeslote vorm van die kanon klem lê op sy selfstandige gesag.

- Die objektiewe benadering beskou al die dele van die kanon as gelykwaardige konstituente daarvan. Dit bring noodwendig die vraagstuk na vore na die eenheid van die kanon. Hierdie vraag stuit egter teen tallose probleme, soos die definisie van eenheid, die rol van die leser wat van buite teoretiseer oor die eenheid wat nie in die kanon self verklaar word nie en die onversoenbare pluriformiteit van teologiese gedagtes wat in die kanon opgeneem is.

- Die subjektiewe benadering worstel met die talle faktore wat vanuit die gemeenskap ' $n$ rol speel om die status van ' $n$ kanon te bepaal. Terwyl die partikulêre en kontingente karakter van kanongebruik beklemtoon word, staan hierdie benadering egter voor die uitdaging om ook die normatiewe dimensie van 'n kanon te akkommodeer.

- Vir die huidige pluriforme situasie lyk dit na die aangewese weg om die normatiwiteit van die kanon nie primêr in terme van rigiede finale literêre vorms te sien nie, maar eerder in sy poging om gesaghebbend oor die ewige God in tydgebonde konsepte en metaforiese beelde te praat. Tegelykertyd moet die eietydse gebruik van die Bybel as kanon binne ' $n$ dinamiese proses van kanonisering en dekanonisering gesien word waarin geen konseptering van die nosie kanon as onveranderlik of ewig gesien word nie. 


\section{Literatuurverwysings}

Adriaanse, H J 1998. Canonicity and the problem of the golden mean, in Van der Kooij, A \& Van der Toorn, K (eds), Canonization and decanonization, 313330. Papers presented to the international conference of the Leiden Institute for the Study of Religions (LISOR) held at Leiden 9-10 January 1997. Leiden: Brill.

Boeve, L 1998. Tradition, (de)canonization, and the challenge of plurality, in Van der Kooij, A \& Van der Toorn, K (eds), Canonization and Decanonization, 371380. Papers presented to the international conference of the Leiden Institute for the Study of Religions (LISOR) held at Leiden 9-10 January 1997. Leiden: Brill.

Deist, F E 1992. Canonical criticism, Reformed theology and developments in the textual criticism of the First Testament. Journal of Northwest Semitic Languages XVIII, 37-47.

God met ons. 1981. GKN-Rapport. Utrecht: Tijl Libertas.

Helmer, C \& Landmesser, C (eds) 2004.One Scripture or many? Canon from biblical, theological and philosophical perspectives. Oxford: Oxford University Press.

Hettema, Th L 1998. The canon: Authority and fascination, in Van der Kooij, A \& Van der Toorn, K (eds), Canonization and decanonization, 391-398. Papers presented to the international conference of the Leiden Institute for the Study of Religions (LISOR) held at Leiden 9-10 January 1997. Leiden: Brill.

Hollander, H W 1998. De canonisering van de echte en onechte brieven van Paulus, in Jenner, K D \& Wiegers, G A (reds), Heilig Boek en religieus gezag: Ontstaan en functioneren van canonieke tradities, 164-183. Kampen: Kok.

Janse, W 1998. Canonisering en decanonisering van de confessie: De reformatie in Duitsland, in Jenner, K D \& Wiegers, G A (reds), Heilig Boek en religieus gezag: Ontstaan en functioneren van canonieke tradities, 231-245. Kampen: Kok.

Jenner, K D \& Wijers, G A 1998. Omtrent het ontstaan en functioneren van canons: de maatschappelijke relevantie van godsdienswetenschappen, in Jenner, K D \& Wiegers, G A (reds), Heilig Boek en religieus gezag: Ontstaan en functioneren van canonieke tradities, 9-22. Kampen: Kok.

Lange, A 2004. From literature to Scripture: The unity and plurality of the Hebrew scriptures in light the Qumran library, in Christine Helmer \& Christoff Landmesser (eds), One Scripture or many? Canon from biblical, theological and philosophical perspectives, 51-107. New York: Oxford University Press.

Loader, J A 2005. The canon as text for a biblical theology. HTS 61, 1027-1043.

Platvoet, J G 1998. Van voor tot voorbij de ene maatstaf: over de canonische fase in de algemene gosdienstgeschiedenis, in Jenner, K D \& Wiegers, G A (reds), Heilig Boek en religieus gezag: Ontstaan en functioneren van canonieke tradities, 93-125. Kampen: Kok Kampen.

Ritschl, D 1998. Bemerkungen zur Koagulation von "Stories" und zum Phänomen der Kanonisierung, in Van der Kooij, A \& Van der Toorn, K (eds), Canonization and decanonization, 381-390. Papers presented to the international conference of the Leiden Institute for the Study of Religions (LISOR) held at Leiden 9-10 January 1997. Leiden: Brill. 
Smith, J Z 1998. Canons, catalogues and classics, in Van der Kooij, A \& Van der Toorn, K (eds), Canonization and decanonization, 295-311. Papers presented to the international conference of the Leiden Institute for the Study of Religions (LISOR) held at Leiden 9-10 January 1997. Leiden: Brill.

Ter Borg, M B 1998. De canon als machtinstruement, in Jenner, K D \& Wiegers, G A (reds), Heilig Boek en religieus gezag: Ontstaan en functioneren van canonieke tradities, 69-80. Kampen: Kok.

Van de Beek, A 1998. Wiens canon accepteren wij? Een protestantse visie op de fundering van de bijbel als canon, in Jenner, K D \& Wiegers, G A (reds), Heilig Boek en religieus gezag: Ontstaan en functioneren van canonieke tradities, 45-66. Kampen: Kok.

Van der Kooij, A 1998. De canonisatie van de Hebreeuse Bijbel (200 vC-100 nC), in Jenner, K D \& Wiegers, G A (reds), Heilig Boek en religieus gezag: Ontstaan en functioneren van canonieke tradities, 147-163. Kampen: Kok.

Van Leeuwen, Th M 1998. Texts, vanon and tevelation, Van der Kooij, A \& Van der Toorn, K (eds), Canonization and Decanonization, 399-409. Papers presented to the international Conference of the Leiden Institute for the Study of Religions (LISOR) held at Leiden 9-10 January 1997. Leiden: Brill.

Vos, H M 1998. De christelijke kanon als keurslijf, in Jenner, K D \& Wiegers, G A (reds), Heilig Boek en religieus gezag: Ontstaan en functioneren van canonieke tradities, 25-44. Kampen: Kok.

Venter, P M 1987. Die kanonbegrip as Bybels-teologiese probleem. HTS 43, 755768.

Venter, P M 1998a. Kanon en teks by Deist. Old Testament Essays 11, 582-599.

Venter, P M 1998b. Wat beteken "kanon" vandag? HTS 54, 505-528.

Venter, P M 2002. The connection between wisdom literature, apocalypses and canon. Old Testament Essays 15, 470-488. 